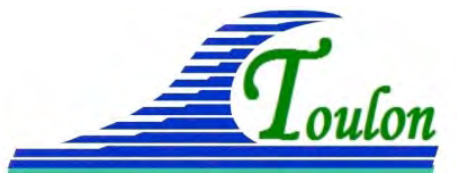

XIV $V^{e ̀ m e s}$ Journées Nationales Génie Côtier - Génie Civil Toulon, 29 juin au $1^{\text {er }}$ juillet 2016

DOI:10.5150/jngcgc.2016.078 (C) Editions Paralia CFL disponible en ligne - http://www.paralia.fr - available online

\title{
Tsunami modelling. Validation of EOLE CFD code on academic test cases
}

\author{
Richard MARCER ${ }^{1}$, Camille JOURNEAU ${ }^{1}$, Kevin PONS $^{1,2}$
}

1. Principia S.A.S., Zone Athélia 1, 215 voie Ariane, 13705 La Ciotat cedex, France. richard.marcer@principia.fr

2. Université de Toulon, IMATH, EA 2134, 83957 La Garde cedex, France.

\begin{abstract}
Into the framework of the TANDEM project, Principia works especially on the qualification of the in-house EOLE CFD software for the simulation of tsunamis. The EOLE code solves 3D multi-phase flows on multi-blocks structured meshes coupled with a free surface tracking VOF model. This paper presents simulations / measurements comparisons for academic test cases of wave generation, propagation, run-up and submersion. On the whole, the results are very satisfactory showing the high potential of the code for tsunamis coastal impact modelling.
\end{abstract}

Keywords: Tsunami, Generation, Propagation, Submersion, CFD modelling, Validation.

\section{Introduction}

This work has been performed by a French national consortium within the framework of the national project Tandem (2014-2017), with aim to improve knowledge about tsunami risk on French coasts. A first step of this project is focused on the qualification of CFD models on academic test-cases covering the main stage of tsunami life, generation, propagation, run-up and submersion.

Three test cases which have experimental data at their disposal are presented in this paper. The benchmarking is carried out with the CFD multiphase EOLE code developed by Principia, for which first validations on tsunami academic test cases can be found in MARCER et al. (2015) and PONS et al. (2015).

After a brief presentation of the model, the paper presents comparisons and validations of the model for the three test cases of physical increasing complexity: simulation of a tsunami induced by a submarine landslide (section 3) and by a vertical fall of a solid block (section 4), impact of a tsunami on a coastal city (section 5 ). 


\section{Presentation of the CFD model}

The EOLE code developed by Principia since 1990 is a multi-phase URANS model solving equations on structured curvilinear multi-blocks meshes (possibly moving and deforming). It is based on a pseudo-compressibility technic using a dual time stepping and a second order finite volume scheme for spatial discretization. The motion of the interface between the different phases is simulated from an implicit VOF model avoiding any CFL constraint. The transport of the VOF function (actually the displacement of the interface) may be ensured by a classical eulerian equation or by an improved eulerian-lagrangian method developed by Principia (GUIGNARD et al., 2001; BIAUSSER et al., 2004).

\section{Tsunami generation and run-up due to a 3D wedge sliding down a slope}

The test-case concerns the modelling of a tsunami generated by a submarine landslide which is represented by a wedge sliding down a 1:2 plane beach slope in the experimental device (LIU et al., 2005). Dimensions of the test bench are given on figure 1. Comparisons are done with measurements from laboratory data published by LIU et al. (2005) which tested different initial wedge positions regarding the free surface height (wedge partially emerged and fully immersed): when the wedge is partially emerged, the top is located at $0.1 \mathrm{~m}$ above the free surface; when it is fully immerged, the top is located at $0.025 \mathrm{~m}$ below the free surface. Wave elevation is monitored at different gauges (wave gauges 1 and 2) whereas the wave run-up is extracted from data on three "runup" gauges which measure here the vertical height (positive or negative) reached by the wave around its initial level $(=0)$.

In the simulation, at initial time the wedge is fully immersed with a depth of $2.5 \mathrm{~mm}$ (distance from the free surface to the top of the wedge) and at rest. Then the block is moved downward along the slope according to a recorded law of motion issued from experiments, with a maximum velocity of $0.22 \mathrm{~m} / \mathrm{s}$ for the fully immerged case and $0.25 \mathrm{~m} / \mathrm{s}$ for the partially emerged case which correspond to Froude numbers of 0.07 and 0.08 . 


\section{XIV ${ }^{\text {èmes }}$ Journées Nationales Génie Côtier - Génie Civil \\ Toulon, 29 juin au $1^{\text {er }}$ juillet 2016}
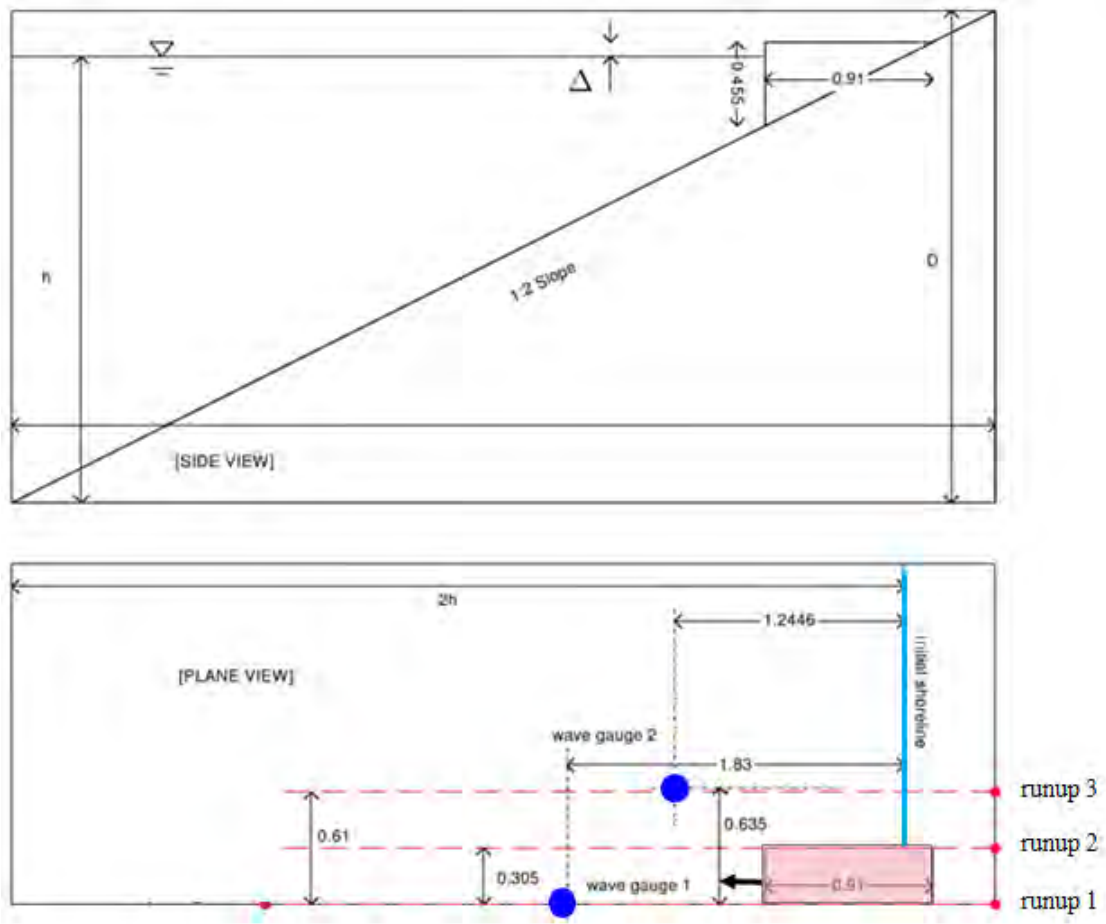

Figure 1. Sketch and dimensions of the test bench for the partially emerged case $(\Delta=0.1 \mathrm{~m})$ - side view and top view (half of the geometry).

Figure 2 shows visualizations of the wave induced by the sinking of the solid. Red and blue colors express respectively the positive and negative elevations of the wave around level 0 . Successive wave crests and troughs are visible (with maximum amplitudes $\approx$ [$10 \mathrm{~cm},+5 \mathrm{~cm}]$ ), and corresponding fluctuations of wave elevations and run up are highlighted on the different gauges (figure 3).

The first trough and crest are correctly reproduced as well as the wavelength of the waves (except a delay on the third crest). Amplitudes of run-up are on the whole satisfactorily reproduced, especially when considering the small values of the fluctuations for run up and elevation to capture in this problem (less than $5 \mathrm{~cm}$ ).

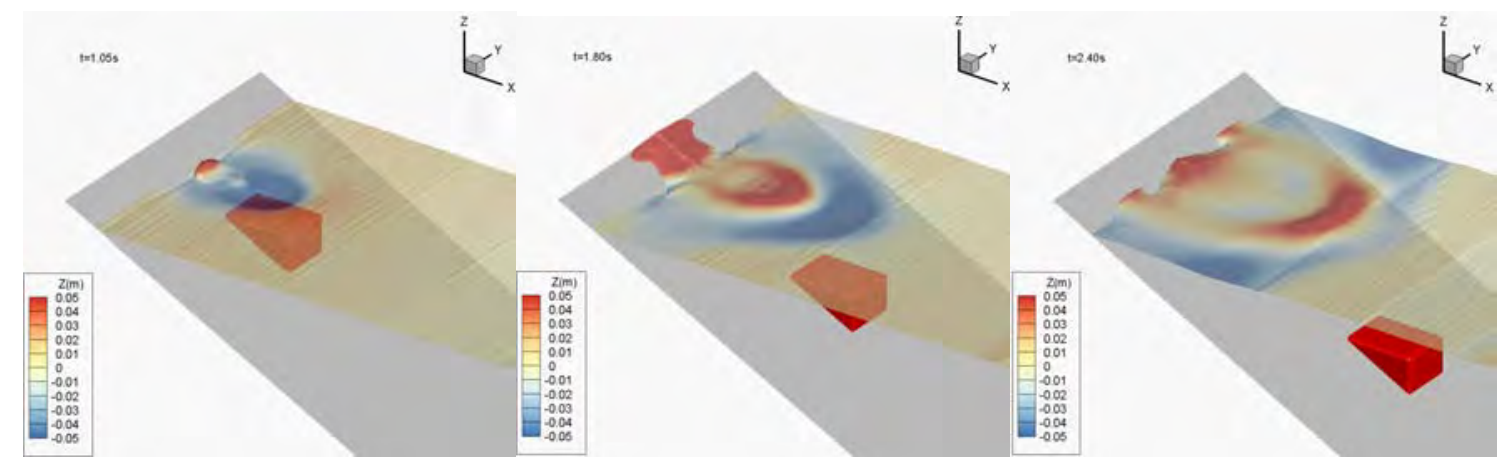

Figure 2. Wave propagation and run-up due to sliding wedge motion $(t=1.05 \mathrm{~s}, t=1.8 \mathrm{~s}$ and $t=2.4 \mathrm{~s}$ from left to right). Fully immerged case $(\Delta=-0.025 \mathrm{~m})$ 


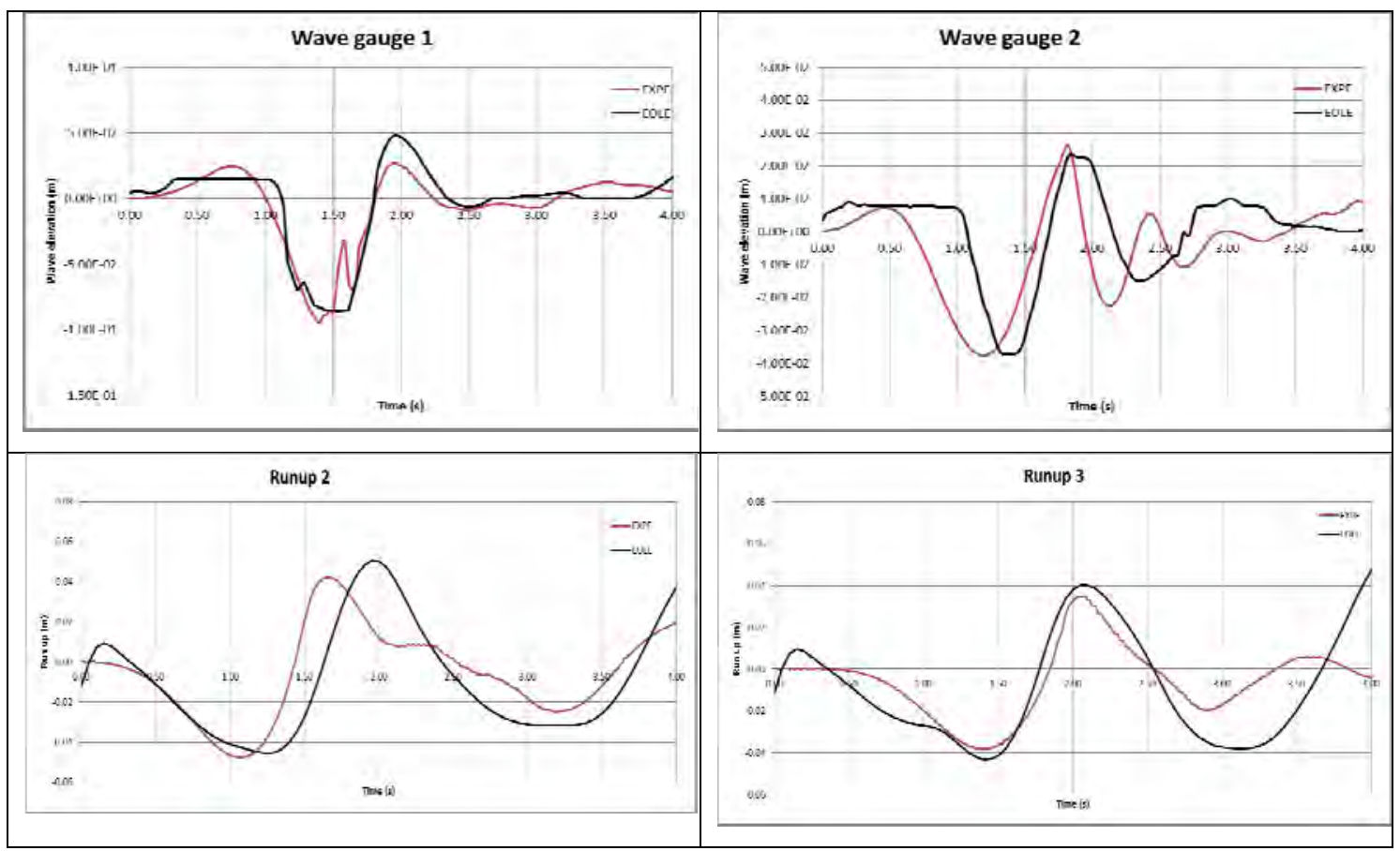

Figure 3. Comparison of wave elevations (wave gauge 1 and wave gauge 2 on top and from left to right) and run-up (runup 2 and runup 3 at bottom and from left to right).

\section{Tsunami generation due to the falling into water of a rectangular rigid body}

The CFD code EOLE is able to well reproduce quite simple cases such as a wedge sliding down but also much more complicated cases such as the falling of a block into water.

The test case is focused on the generation of a solitary wave induced by the vertical fall of a rectangular rigid body and its interaction with the underlying water free surface. It is based on the experiment published in MONAGHAN and KOS (1999). This benchmark allows checking the accuracy of the model in case of strong interactions of a rigid body with the free surface. It involves fluid/rigid solid coupling, interface breakup/reconnections and vortices generation, and thus requires the use of models able to deal with these kinds of complex phenomena. In terms of engineering relevance, this case is close to the physics involved in massive cliffs or ice bodies falling into water.

Figure 4 represents a sketch of the experimental device with a $9 \mathrm{~m}$ long 2D flume and with water depth D. A $38.2 \mathrm{~kg}$ rectangular block $(0.4 \mathrm{~m}$ tall, $0.3 \mathrm{~m}$ long and $0.39 \mathrm{~m}$ wide) is placed just below still water level at initial time, and then released. Experiments were carried out for three depths, $\mathrm{D}=0.288,0.210$, and $0.116 \mathrm{~m}$. In each case, the vertical block position and free surface elevation were measured as a function of time at a wave gauge located $1.2 \mathrm{~m}$ from the leftward extremity of the flume. Values of $\mathrm{H}$ and $\mathrm{B}$ (figure 4) were also estimated from video measurements. 


\section{XIV èmes Journées Nationales Génie Côtier - Génie Civil \\ Toulon, 29 juin au $1^{\text {er }}$ juillet 2016}

To solve the fluid solid interaction, EOLE calculates the block motion from the mechanic law considering the resulting pressure and viscous loads applied on the solid boundaries.

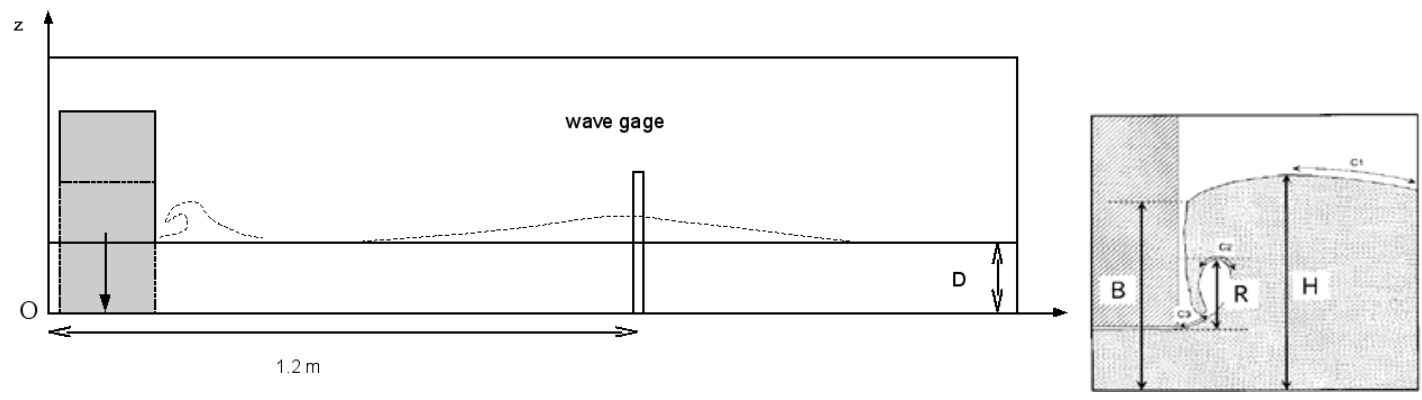

Figure 4. Sketch and dimensions of the experimental device.
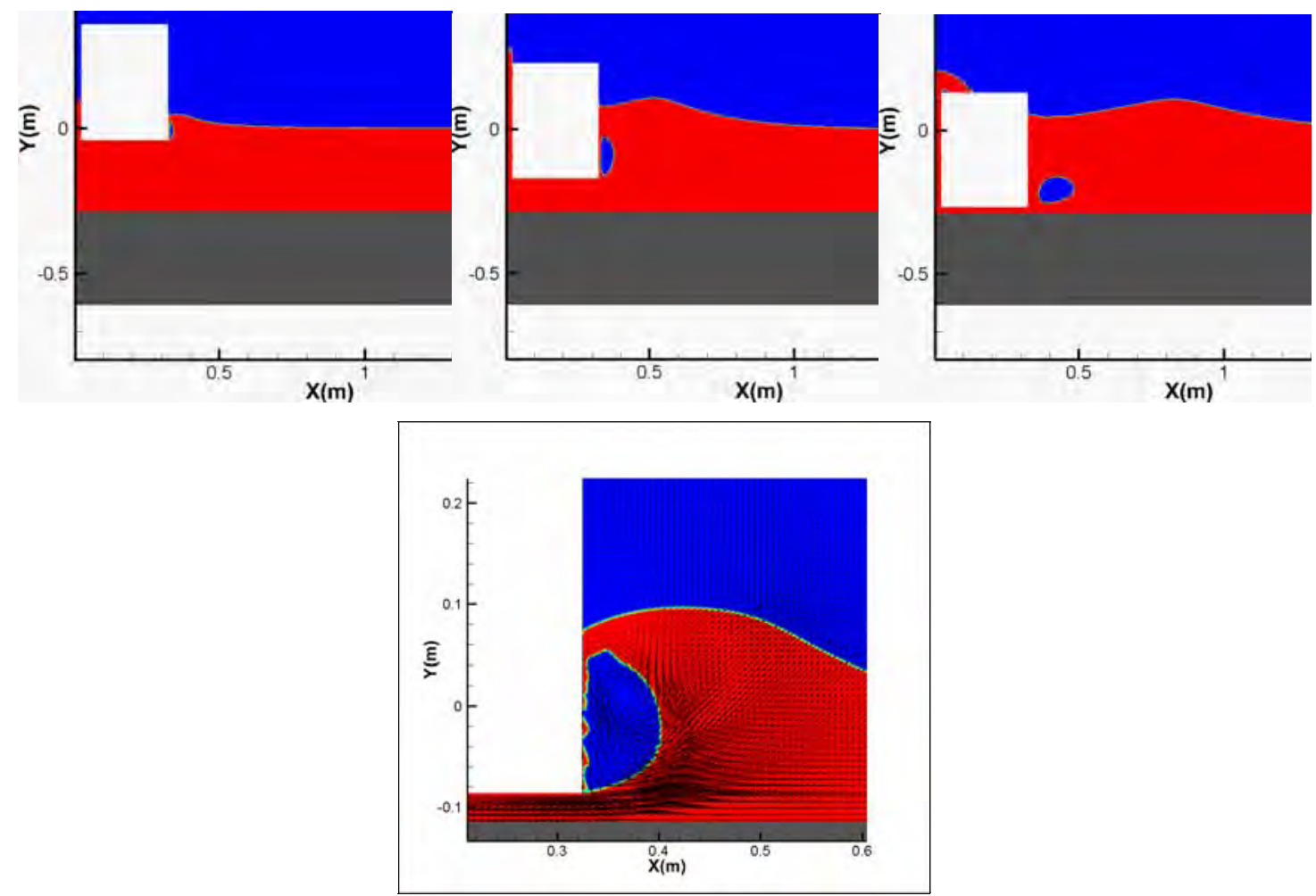

Figure 5. Snapshots of the wave evolution induced by a falling block (top) - zoom of the flow velocity when the wave is forming (bottom).

Figure 5 presents snapshots of the simulation carried out with the model for a water depth $\mathrm{D}=0.210$. A solitary wave is generated due to interaction with the falling block, and propagates downstream of the flume. Near the block the flow is complex with different physical phenomena that the model is able to put into evidence, especially thanks to the VOF free surface method: enclosed air bubble, vortex development fed by 


\section{Thème 7 - Risques côtiers}

the downward motion of the rigid block, break-up of the tip of the wave pulled by the moving solid wall.

An important issue is the accuracy with which the block motion is simulated from the fluid/solid (rigid) coupling model. Figure 6 shows that very satisfactory results are obtained on this point.

Table 1 summarizes the wave height (A) simulated by the model a few solid lengths away from the source position, for various initial water depths. The free surface shape close to the solid motion is characterized as well for an initial depth of $0.210 \mathrm{~m}$.

The numerical estimations generally show a very good accuracy proving the ability of the model to simulate the waves generated by a rigid body vertically falling into water taking into account the fluid/solid interaction.

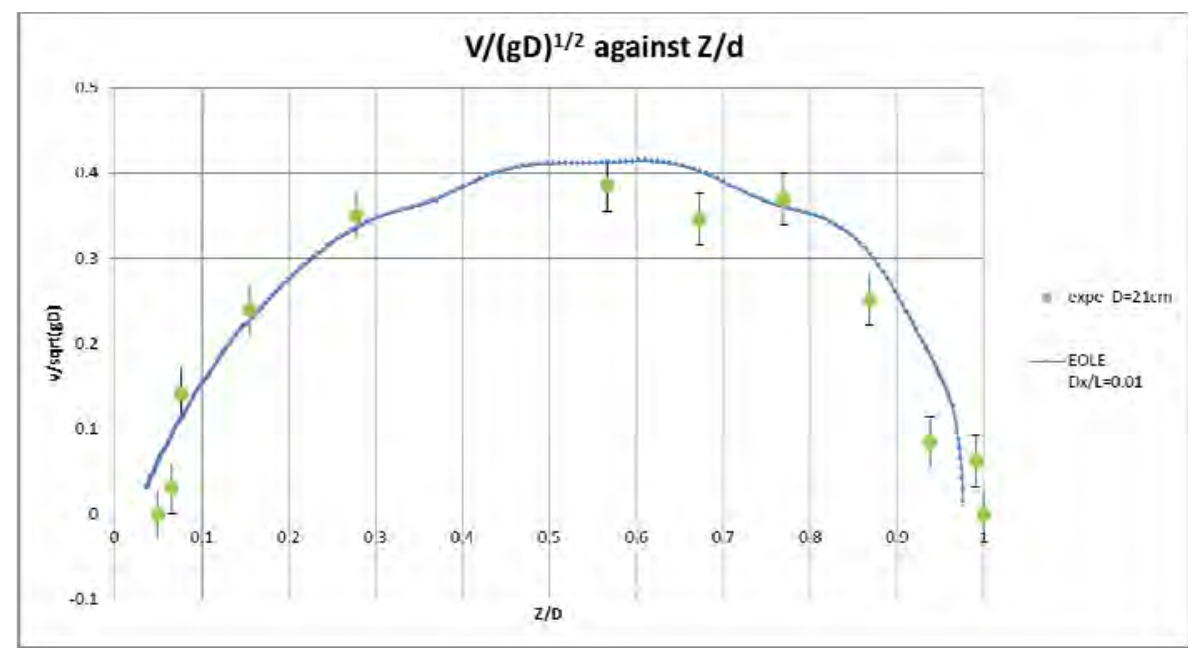

Figure 6. Block velocity (V) versus vertical position (curve to be read from right to left with increasing time) - symbols: experiments; line: simulation.

Table 1. Comparison of wave height (A) monitored at $x=1.2 \mathrm{~m}$ for three different water depths, and comparison of B and H parameters (Fig 4) obtained for the depth $D=0.210$.

\begin{tabular}{llllll}
\hline \multirow{5}{*}{} & \multicolumn{5}{l}{$\mathrm{D}(\mathrm{m}):$ water depth } \\
\cline { 2 - 6 } & 0.116 & 0.210 & 0.288 & 0.210 & \\
\cline { 2 - 6 } & $\mathrm{A}$ & & & $B$ & $H$ \\
\hline Experiment & $0.109( \pm 0.01)$ & $0.092( \pm 0.01)$ & $0.093( \pm 0.01)$ & $0.303( \pm 0.02)$ & $0.333( \pm 0.01)$ \\
EOLE & 0.096 & 0.094 & 0.095 & 0.291 & 0.317 \\
\hline
\end{tabular}

\section{Impact of a tsunami on a coastal city}

This experimental case has been done in the Oregon State University basin (PARK et al., 2013). A complex topography has been realized including a seawall and several buildings, inspired of the real city of Seaside (Oregon) at a 1/50 scale. The dimensions of the basin are $49 \mathrm{~m}$ long, $26.5 \mathrm{~m}$ wide and $2.1 \mathrm{~m}$ depth offshore. The experiment consisted in generating a solitary wave $(0.2 \mathrm{~m}, 10 \mathrm{~s})$ with a piston-type wavemaker which 


\section{XIV èmes Journées Nationales Génie Côtier - Génie Civil \\ Toulon, 29 juin au $1^{\text {er }}$ juillet 2016}

was designed to correspond to the estimated tsunami wave height for the "500 years" CSZ (Cascadia Subduction Zone) tsunami. More than thirty sensors (elevations, velocity) were placed mostly in the city at different positions between buildings (Fig. 7). The curvilinear multiblock mesh of the model uses variable discretization on each spatial direction and includes 9 million cells. On the average the step size is about 20 $\mathrm{cm}$ on the horizontal and $2 \mathrm{~cm}$ on the vertical for the offshore area ; in the city a refinement is applied with a cell size of about $5 \mathrm{~cm}$ on the horizontal and $1 \mathrm{~cm}$ on the vertical.

All the boundaries (including the ones at the domain borders) are supposed to be walls as in the basin experiments.

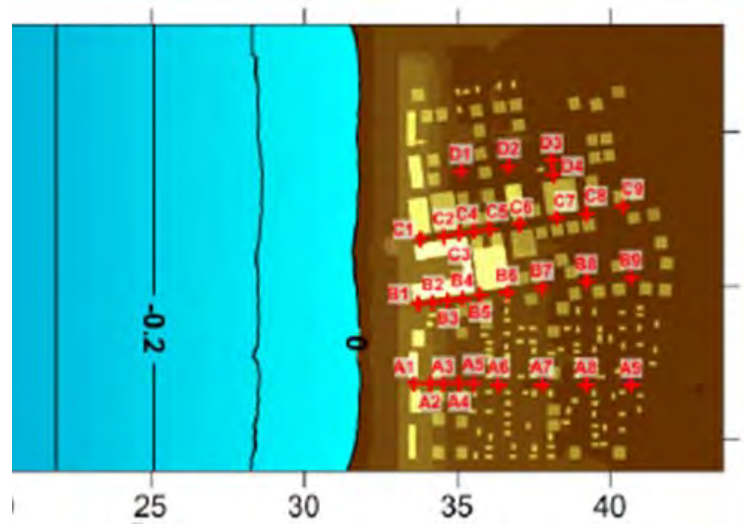

Figure 7. Experimental model of the city and positions of the sensors.

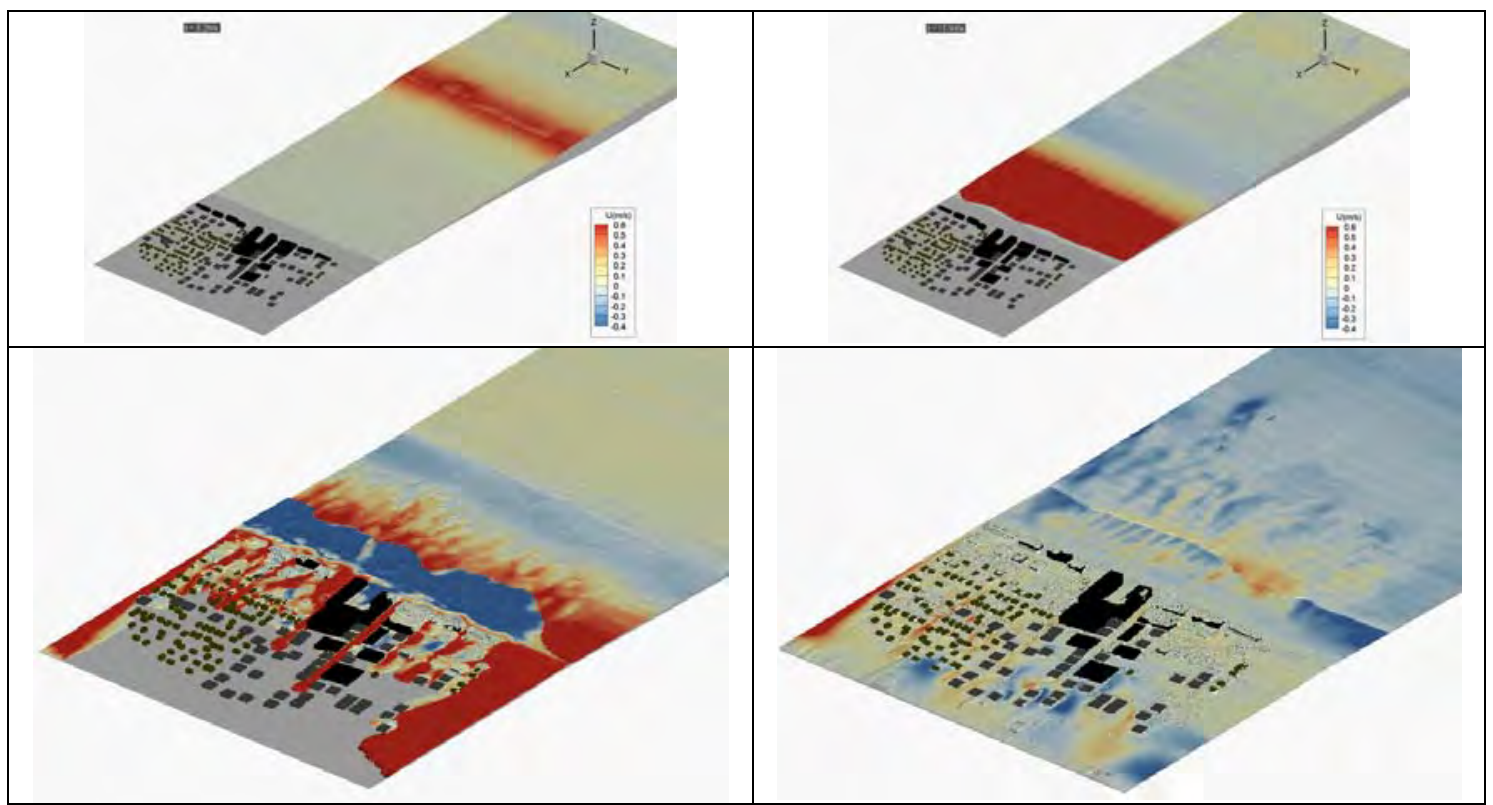

Figure 8. Simulation with EOLE of a tsunami impacting a coastal city $(t=3 \mathrm{~s}, t=12 \mathrm{~s}$, $t=18 \mathrm{~s}, t=34 \mathrm{~s}$ respectively from top to bottom and left to right). 


\section{Thème 7 - Risques côtiers}

Figure 8 shows snapshots of the offshore wave propagation, the wave breaking when arriving close to the coast and the tsunami impact against the buildings of the city. Red and blue colors express respectively the positive wave propagation velocity (Umax $\approx 1 \mathrm{~ms} / \mathrm{s}$ ) and the reflecting wave velocity (Umin $\approx-0.5 \mathrm{~ms} / \mathrm{s}$ ) around level 0 (in white). Comparisons with measurements are done at two different instants of the flooding process (figure 9). Very good results can be noticed for the flooding according to the layout of the city, as well as the reflecting wave by the buildings. Accuracy of the model is confirmed regarding direct comparisons of elevation and velocity time series on sensors (see example on figure 10).

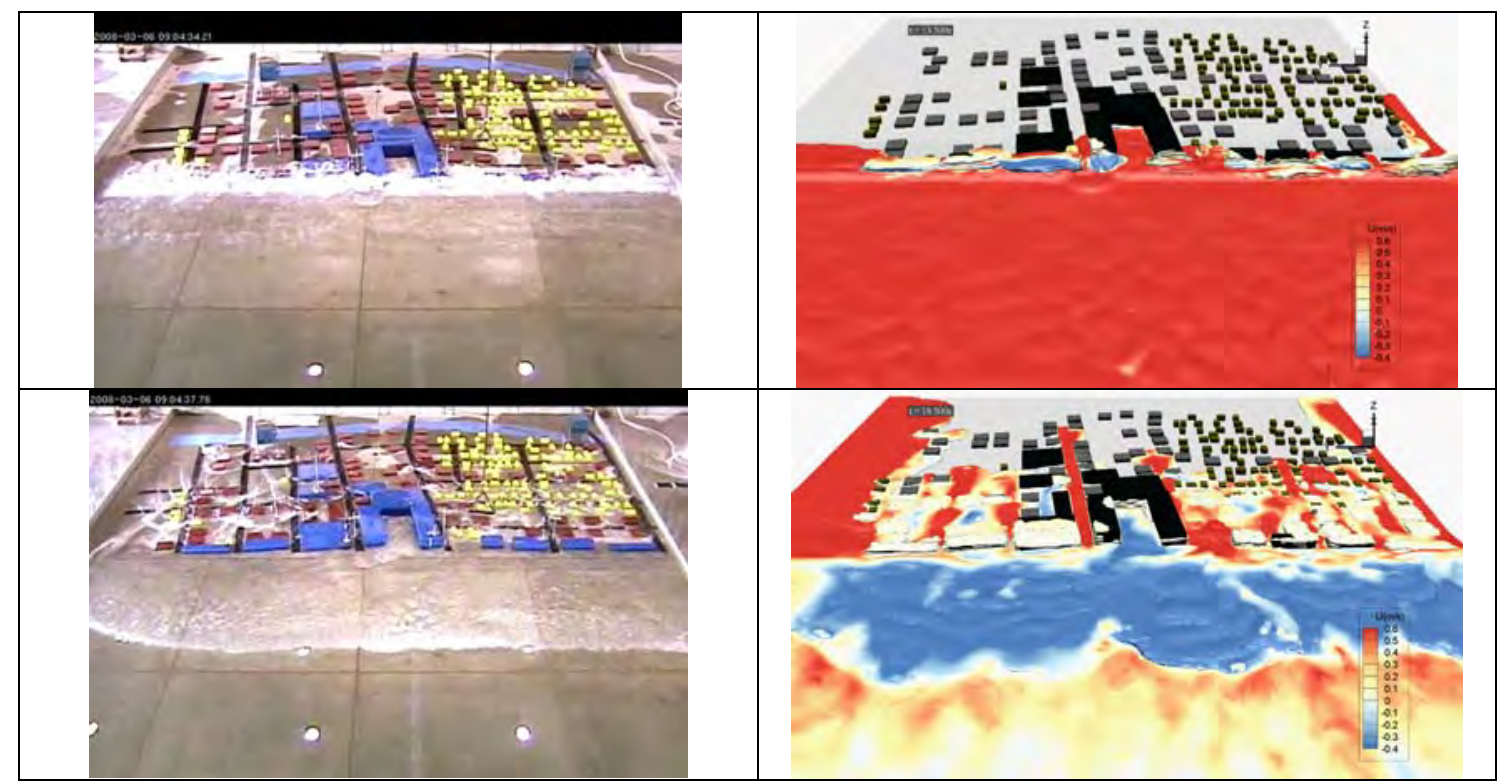

Figure 9. Comparisons of the wave field at two instants. 


\section{XIV ${ }^{\text {èmes }}$ Journées Nationales Génie Côtier - Génie Civil \\ Toulon, 29 juin au $1^{\text {er }}$ juillet 2016}

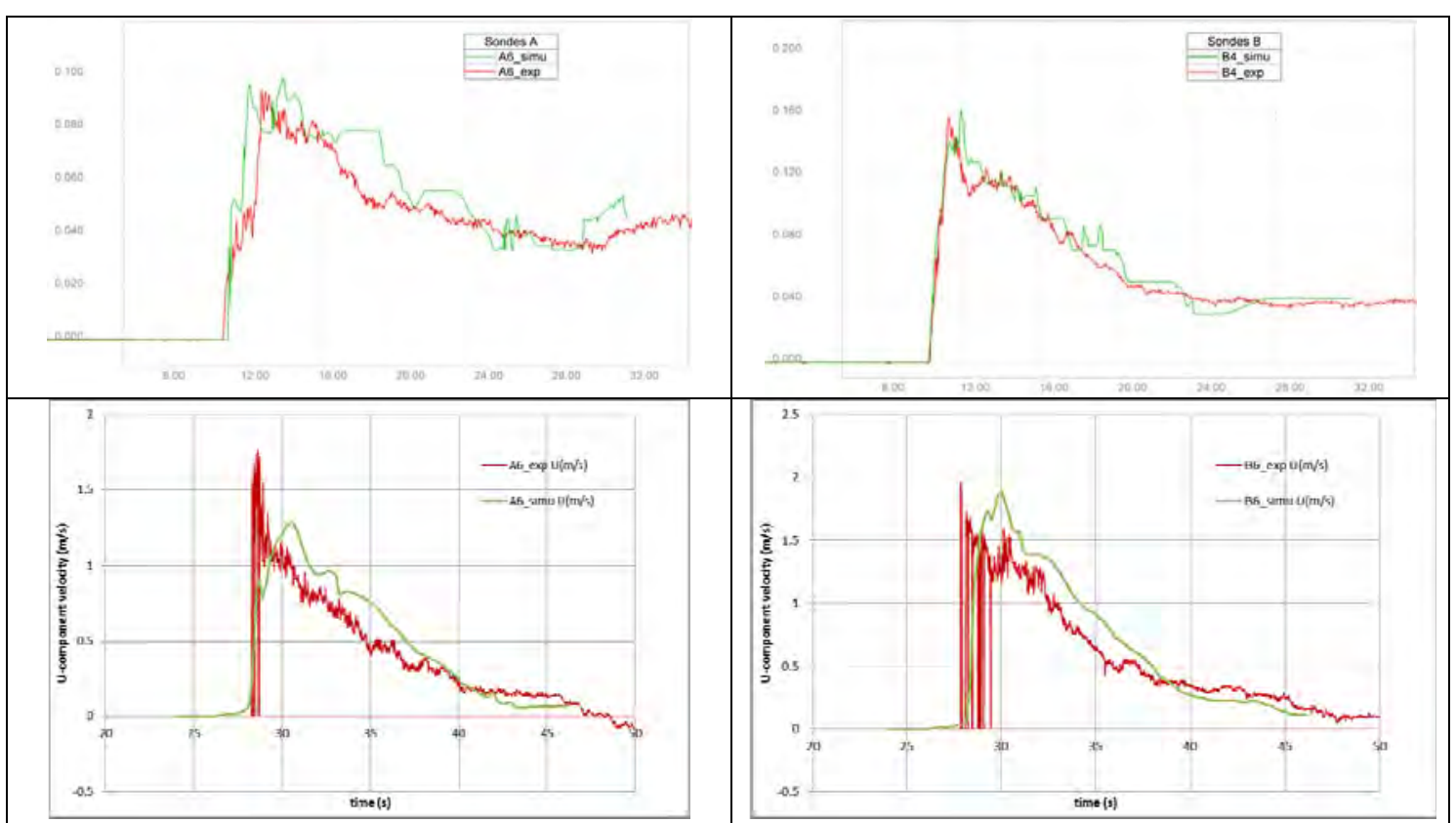

Figure 10. Example of comparisons on different sensors - A6 and B4 for elevation (top)

- A6 and B6 for velocity (bottom) - EOLE in green - Experiments in red.

\section{Conclusions}

Results shown in this paper demonstrate the ability of the EOLE code to simulate the main stages of tsunami, generation, propagation, run-up and submersion. Especially, high level of validation and accuracy is noticed regarding the modelling of different complex physics such as, large deformation of the free surface up to break-up, enclosed air bubbles issued from vortices of the flow during the wave breaking, and motion of a solid interacting with the flow (coupling fluid / mechanics of the rigid solid). Further validations are still in progress into the framework of the TANDEM project, especially for simulation of tsunamis issued from earthquakes. In particular a coupling model (2D Saint-Venant / 3D Navier-Stokes) is ongoing and will allow to simulate the tsunami propagation from the source at large scale (2D) up to the coastal impact (3D).

\section{Aknowledgments:}

TANDEM = Tsunamis in the Atlantic and the English ChaNnel et MaNche : Definition of the Effects through numerical Modeling (2014-2018): a French initiative to improve tsunami hazard assessment in France.

TANDEM is supported through the French PIA grant ANR-11-RSNR-00023 of the program Recherches en matière de Sûreté Nucléaire et Radioprotection. 
Thème 7 - Risques côtiers

\section{References}

BIAUSSER B., MARCER R., GUIGNARD S., FRAUNIE P. (2004). 3-D two phase flows numerical simulations by SL-VOF method. Intl. J. for Num. Meth. Fluids, Vol. 45, pp 581-604. http://dx.doi.org/10.1002/fld.708

GUIGNARD S., MARCER R., REY V., KHARIF C., FRAUNIE P. (2001). Solitary wave breaking on sloping beaches : $2 D$ two phase flow numerical simulation by SLVOF method. Eur. J. Mech. B, Fluids, Vol. 20, pp 57-74. http://dx.doi.org/10.1016/s09977546(00)01104-3

LIU P.L.F., WU T.-R., RAICHLEN F., SYNOLAKIS C.E., BORRERO J.C. (2005). Runup and rundown generated by three-dimensional sliding masses. J. Fluid Mech. Vol. 536, pp 107-144. http://dx.doi.org/10.1017/S0022112005004799

MARCER R., PONS K., JOURNEAU C., GOLAY F. (2015). Validation of CFD models for tsunami simulation, Revue Paralia, Vol. 8, pp n04.1-n04.06. http://dx.doi.org/10.5150/revue-paralia.2015.n04

MONAGHAN J.J., KOS A. (2000). Scott Russell's wave generator. Physics of Fluids, Vol. 12(3), pp 622-630. http://dx.doi.org/10.1063/1.870269

PARK H., COX D.T., LYNETT P.J., WIEBE D.M., SHIN S. (2013), Tsunami inundation modeling in constructed environments: A physical and numerical comparison of free-surface elevation, velocity, and momentum flux. Coastal Engineering, Vol. 79, pp 9-21. http://dx.doi.org/10.1016/j.coastaleng.2013.04.002

PONS K., JOURNEAU C., MARCER R., GOLAY F. (2015). Calculs CFD de propagation et d'impact de vague en zone côtière. 33èmes Rencontres de l'AUGC, ISABTP/UPPA, Anglet, France, 27-29 May 2015. 